\title{
3P: ÉLETKÉPTELEN JOGALKOTÁSI VADHAJTÁS VAGY A KÖZÖSSÉGI IGÉNYEK KIELÉGÍTÉSÉNEK MÜKÖDŐKÉPES ALTERNATÍVÁJA?
}

\author{
Varga Judit ${ }^{2}$
}

Három P, vagyis PPP, mely akroníma a Public-PrivatePartnership, azaz a köz- és magánszektor partnersége kifejezés röviditése, a 2000-es évek elejétöl rendszeres idöközönként fel-felbukkan a hazai médiumokban, hol pozitiv, s az elmúlt években egyre inkább negatív kontextusban. A börtönök, illetve önkormányzati sportberuházások után most - mint ahogy láthatjuk híreink között is - a felsöoktatási PPP konstrukciók kiváltása kerül teritékre Magyarországon. De mégis, mennyi ilyen volt, van és végül kié is lesz?

Az 1990-es évek végén, 2000-es évek küszöbén jelentek meg az első szük értelemben vett PPP szerződések Magyarországon lehetőségként arra, hogy államháztartáson kívüli források bevonásával valósítsanak meg komoly tökeigényü és szükségesnek ítélt infrastrukturális beruházásokat: autópályákat, kollégiumokat, börtönöket vagy sportlétesítményeket hozva létre. Egy évtizeddel később lehetőségböl költségvetési kolonccá váltak a korábban kötött ilyen megállapodások. 2010-ben beindult felülvizsgálatuk, 2011-től pedig egymást követték a hol sikeres, hogy kevésbé sikeres kivásárlási kísérletek. Valóban életképtelen jogalkotási vadhajtásról volna szó, melyet tövestől kell kigyomlálni? Ha így van, akkor miért bukkan fel a PPP típusjegyeit viselő megoldás a Diósgyőri Stadion rekonstrukciója kapcsán?

A közösségi igények kielégítése során, s ezeken belül a közfeladatok ellátásában mind a mai napig meghatározó szerepe van az államnak. A közösségek állammá szerveződésétől kezdve azonban a társadalom egészének, s persze az azt alkotóegyes egyéneknekaz igénye is változik, bővül, mely elvárásoknak az állam igyekszik eleget tenni, gondoljunk csak például az első, második, illetve harmadik generációs alapjogok kialakulására, s általuk az államra háruló feladatok ellátásra. Az állammal szembeni elvárás, s így az állam feladata kezdetben az egyén és tágabb közösségének védelmében manifesztálódott, ám mára ezen jócskán túllépett. A közösségi igények kielégítése komoly forrásokat emészt fel, s ahogy az igények bővülnek, $\mathrm{s} a$ közösségi szolgáltatásokkal szembeni minőségi elvárások egyre nőnek, úgy a szolgáltatást nyújtóknak is egyre mélyebben kell a zsebükbe nyúlniuk. Az állam és intézményei, vagyis a közszektor, mint közfeladat-ellátási szektor a kiszolgált közösség, társadalom nyomására egyre több és több feladatot, szolgáltatást kénytelen felvállalni. Ám mindenki, ez alól a közszektor sem kivétel, számolni kénytelen azzal a ténnyel, hogy az erőforrások korlátozottan állnak rendelkezésre. Az állami intézmények, szervek által biztosított közszolgáltatások köre, illetve minősége nem bővíthető és növelhető a végtelenségig a költségvetési keretek miatt. Persze a közbevételek növelhetök különböző technikákkal (pl. adóemelés, hitelfelvétel), amelyek vagy a közösség ellenállásába, vagy gazdasági korlátokba ütköznek, vagy egyszerre mindkettőbe, s így hosszú távon nem garantálnak fenntartható megoldást a hiányzó források pótlására.

\footnotetext{
"A tanulmány a Magyar Tudományos Akadémia és a Debreceni Egyetem Állam- és Jogtudományi Kar közös, MTA-DE Közszolgáltatási Kutatócsoportjának a Területi közszolgáltatások szabályozásai címü projektje keretében készült. A projekt leírására 1.: Horváth M.T.: Szempontok a területi közszolgáltatások regulációs változásainak vizsgálatához. In: HMT (szerk.) Kilengések. Közszolgáltatási változások. Budapest: Dialóg Campus, 2013. 9-25. old.

${ }^{12}$ Varga Judit, egyetemi tanársegéd, DE-ÁJK
} 
A fenti probléma viszont hatékonyan kezelhetőnek bizonyult a különböző alternatív közfeladat-ellátási módszerekkel. Ezek olyan szolgáltatásszervezési megoldások, amelyek során a közfeladatok az állam koordinálása mellett (az állam szabályozási és szervezési funkciója), de jellemzően más, közszektoron kívüli szereplők által kerülnek megvalósításra, elöbbi alanyok forrásainak, vagyis államháztartáson kívüli eszközöknek a bevonásával. Az állam tehát előbbi esetekben együttműködik más szektorok szereplőivel, például a non-profit civil vagy egyházi szektor, vagy a profitorientált magánszektor alanyaival a közösségi igények kielégítése során. Számos alternatív közfeladat-ellátási megoldás különböztethető meg, melyek napjainkra már a közösségi igények kielégítésének szerves részévé váltak.

Alternatív közfeladat-ellátási módszerek csoportosítása

1. táblázat

\begin{tabular}{|c|c|c|}
\hline Közjogi megoldások & $\begin{array}{l}\text { Közjogi és magánjogi } \\
\text { megoldások }\end{array}$ & Magánjogi megoldások \\
\hline \multirow{5}{*}{ támogatáscsökkentés } & $\begin{array}{l}\text { szerződések (pl. adás-vételi } \\
\text { szerződés, bérleti szerződés stb.) } \\
\text { közbeszerzési értékhatár felett }\end{array}$ & $\begin{array}{l}\text { szerződések (pl. adás-vételi } \\
\text { szerződés, bérleti szerződés stb.) } \\
\text { közbeszerzési értékhatár alatt }\end{array}$ \\
\hline & $\begin{array}{l}\text { közigazgatási szerződések (pl. } \\
\text { PPP-szerződések (szük } \\
\text { értelemben), közfeladat-ellátási } \\
\text { megállapodások stb.) }\end{array}$ & \multirow{4}{*}{$\begin{array}{c}\text { önkéntesség és önsegítő } \\
\text { szervezetek (Ha nincs állami } \\
\text { támogatás.) }\end{array}$} \\
\hline & Társulások & \\
\hline & $\begin{array}{l}\text { önkéntesség, önsegítő szervezetek } \\
\text { (Ha van állami támogatás.) }\end{array}$ & \\
\hline & díjpolitikai eszközök & \\
\hline
\end{tabular}

Forrás:a szerző saját szerkesztése

Számtalan eset van, amikor az állam, mint gazdasági szereplő szerződik profitorientált magánjogi jogalannyal valamilyen közfeladat ellátása érdekében, s a kontraktusban részes felek együttmüködését közjogi normák is „körülbástyázzák” egyrészt a közfeladat ellátásának garanciájaként, másrészt az elköltésre kerülő közpénzek biztosítékaként. Gondoljunk csak a közbeszerzési eljárások végeredményeként születő megállapodásokra, a vagyonkezelési szerződésekre, vagy akár a PPP szerződésekre. Ezek mind, mind a köz- és magánszektor között születő olyan szerződéses megállapodások, melyek tágabb értelemben (funkcionálisan) PPP-nek tekinthetők (1. táblázat, sárga cellák). Számtalan példát láthatunk ezekre napjainkban, hazánkban is. . A tágabb értelemben vett PPP-n belül találjuk a szükebb értelemben felfogott, vagy szerződéses PPP-t, melynek szintén számos fajtáját különböztethetjük meg. A szükebb értelemben vett PPP mindegyike szerződéskomplexum, azaz több polgári jogi értelemben vett tipikus szerződés (pl. adásvételi, bérleti, vállalkozási szerződés) komplex rendszere, mely keretében születő együttműködés hosszú távra jön létre a központi vagy helyi kormányzat és a profitorientált magánszektorbeli alany(ok) között. A partnerség célja föszabály szerint valamilyen infrastrukturális beruházás létrehozása és/vagy kapcsolódó szolgáltatás nyújtása egy, a szerződésben meghatározott időintervallumon keresztül vagy időpontig. A szerződésben vállalt kötelezettségekért cserébe az ellentételezés alapulhat direkt módon a fogyasztó által a szolgáltatásért fizetett díjakon, vagy a kormányzat által, teljesítményalapon megállapított kifizetéseken.E szükebb értelemben felfogott PPP-k azok, melyek politikai támogatottsága megszünt, s a már megkötött ilyen szerződések felülvizsgálata pedig megkezdődött 2010-ben Magyarországon.

A PPP aktuális, létező jogintézmény nemzetközi és hazai vonatkozásokban is. Hazánkban bár valóban megszünt a szükebb értelemben vett PPP-k, mint közfeladat-ellátási alternatívák preferálása, azonban tény, hogy a korábban megkötött ilyen szerződések egy része még ma is fut, müködik, s így a központi költségvetésben évente kiadásként jelentkeznek. 
A központi költségvetési törvényben szükebb értelemben vett PPP szerződésre elkülönített kiadási előirányzatok hazánkban 2010-2015 között

\begin{tabular}{|c|c|c|}
\hline Év & $\begin{array}{c}\text { Közfeladat-ellátási } \\
\text { terület }\end{array}$ & Millió Ft \\
\hline \multirow{4}{*}{2010} & Sportlétesítmények & 1529 \\
\hline & oktatási terület & 9481,3 \\
\hline & Autópálya & 74720,1 \\
\hline & MÜPA & 8667,1 \\
\hline \multirow{4}{*}{2011} & Sportlétesítmények & 1539,7 \\
\hline & oktatási terület & 9413,3 \\
\hline & Autópályák & 99186,3 \\
\hline & MÜPA & 9896,9 \\
\hline \multirow{3}{*}{2012} & $\begin{array}{l}\text { oktatási, kulturális és } \\
\text { sport programok }\end{array}$ & 21061,3 \\
\hline & $\begin{array}{l}\text { kivásárlásra elkülönített } \\
\text { összeg }\end{array}$ & 15000 \\
\hline & Autópályák & 99308 \\
\hline \multirow[t]{2}{*}{2013} & $\begin{array}{l}\text { oktatási, kulturális és } \\
\text { sport programok }\end{array}$ & 21102 \\
\hline & Autópályák & 103200 \\
\hline \multirow{4}{*}{2014} & Sportlétesítmények & 890,8 \\
\hline & oktatási terület & 8659,6 \\
\hline & Autópályák & 107200 \\
\hline & MÜPA & 11514,3 \\
\hline \multirow{3}{*}{2015} & Sportlétesítmények & 828,5 \\
\hline & Autópályák & 114276,9 \\
\hline & MÜPA & 11576,6 \\
\hline Összeser & & 729051,7 \\
\hline
\end{tabular}

Forrás: a szerző saját szerkesztése

További érdekesség, hogy a 1037/2015. (II.9.) Korm. határozatból ${ }^{13}$ olyan infrastruktúrafejlesztési megoldás olvasható ki, mely a szüken értelmezett PPP-vel rokon vonásokat mutat. Ilyen sajátossága a beruházásnak, hogy a szóban forgó stadion építetőjeként eljáró profitorientált gazdasági társaság tulajdonába kerül a majdan létrejövő sportlétesítmény, melynek piaci alapon történő hasznosítására vállal kötelezettséget a társaság. Fontos azonban, hogy a projekttársaság a magyar állam 100\%-os tulajdonában áll. Az állam, így mintegy magával, mint profitorientált gazdasági szereplővel „szerződik” közösségi igény kielégítésére, speciális PPP szerződést hozva ezzel létre, amitPUP-nak (Public-Public Partnership) rövidít a nemzetközi szakirodalom.Ahogy azt korábban említettem a szüken felfogott PPP-nek több típusa különböztethető meg, egyik ilyen típusa a koncesszió is, mely szerződéseknek igen hosszú múltja van Magyarországon, s felszámolásuk gondolata nem merült fel.A szükebb értelemben vett PPP szerződések mellett továbbra is igen intenzíven jelen van a tágan felfogható PPP hazánkban, akár a vagyongazdálkodásiszerződésekre, akár a közbeszerzési eljárás eredményeként születő megállapodásokra gondolunk. A köz- és magánszektor közötti együttmüködés a közfeladat-ellátást illetően létezik, s napjainkra olyan mértéket öltött, hogy szükségszerünek tekinthetö. A szektorok közötti együttmüködés eszközei változnak, az egyes eszközök közti súlyarányok eltolódnak, ám ha a PPP-t akár tágan, akár szüken értelmezzük, megállapíthatjuk, hogy az ma is része a közösségi igények kielégítésének Magyarországon.

A PPP jogintézményének hazai terjedésében kulcsszerepe volt az Európai Uniónak. A PPP az egyes tagállamokban továbbra is nagy népszerüségnek örvend, melyet az Európai

\footnotetext{
${ }^{13} 1037 / 2015$. (II.9) Korm. határozat a Nemzeti Stadionfejlesztési Program keretében megvalósuló Diósgyőri Stadion rekonstrukciójához kapcsolódó intézkedésekről.
} 
Beruházási Bank (EBB) által PPP konstrukciók megvalósítására nyújtott támogatások ${ }^{14}$ tovább erősítenek. Ezt támasztja alá az EPEC (European PPP Expertise Centre) adatbázisa is ${ }^{15}$.

3. táblázat

Az Európai Beruházási Bank által finanszírozott PPP szerződések közfeladat-ellátási területenként éves bontásban 2010-2014 között

\begin{tabular}{|c|c|c|}
\hline Év & Közfeladat-ellátási szektor & Millió euró \\
\hline \multirow{4}{*}{2010} & Energia & 30 \\
\hline & Közlekedés & 2127 \\
\hline & Oktatás & 45 \\
\hline & Egészségügy & 986 \\
\hline \multirow{3}{*}{2011} & Közlekedés & 2564 \\
\hline & Víz- és csatornarendszer & 142 \\
\hline & Egészségügy & 128 \\
\hline \multirow{2}{*}{2012} & Közlekedés & 948 \\
\hline & Oktatás & 50 \\
\hline \multirow{4}{*}{2013} & Közlekedés & 2182 \\
\hline & Egészségügy & 360 \\
\hline & Oktatás & 95 \\
\hline & Szilárd hulladék & 120 \\
\hline \multirow{4}{*}{2014} & Közlekedés & 2625 \\
\hline & Egészségügy & 400 \\
\hline & Oktatás & 36 \\
\hline & Szilárd hulladék & 198 \\
\hline \multicolumn{2}{|l|}{ Összesen: } & 13036 \\
\hline
\end{tabular}

Forrás: a szerző saját szerkesztése

A fenti állítást, hogy a PPP nemzetközi értelemben is élő, müködő eszköze a közösségi igények kielégítésének, nem csak az Unióhoz tartozó adatbázisokkal, hanem más nemzetközi szervezetek (pl. Világbank), illetve az egyes nemzetállamok nyilvántartásaival is alá lehet támasztani.

A tárgyalt jogintézmény azonban nem „,csak” létezik, fejlődni is képes. A fejlődés két dimenzióra bontható. Egyrészt a felmerülő új igényekhez alkalmazkodva például a Horizont 2020 Keretprogramban a kutatás-fejlesztésbe is bevonják a PPP-t, s így a magántőkét, holott a jogintézményt megjelenésekor a jelentős tőkeigényü infrastrukturális beruházások megvalósítására és a hozzájuk kapcsolódó szolgáltatások nyújtására hívták segítségül. A másik iránya a fejlődésnek, hogy újra gondolták a részes feleket, s felmerült, hogy ne csupán profitorientált szervezeteket és azok tökéjét vonják be a partnerségben megvalósuló közfeladat-ellátásba, hanem akár a non-profit szektor is, így hívva életre a PPP egy új típusát a PUP-ot (Public-Public Partnership), amelyben a kormányzat más közszektorbeli vagy civil széférából származó alannyal szerződik egy adott közösségi igény kielégítésére. Ebből az aspektusból a PPP egy élő, működő, organikus jogintézmény, mely képes az őt életre hívó folyton változó társadalmi igényekhez igazodni.

Ugyanakkor nem minden megkötött szerződés váltja be a felek reményeit, gondoljunk csak a hazai felsőoktatási PPP projektek kivásárlására. ${ }^{16}$ Előbbi esemény jelzésértékü, ám a jogintézményben rejlő potenciálra vonatkozó messze menő következtetések levonására nem alkalmas, hisz a szerződések felszámolását több tényező is elősegítheti, indokolhatja, mint a változó szakpolitikai célok vagy a költségvetési, gazdaságossági megfontolások.

\footnotetext{
${ }^{14}$ http://www.eib.org/attachments/thematic/eib ppp en.pdf (Letöltés: 2015. 09. 07.)

15 http://www.eib.org/epec/index.htm

16 http://www.kozjavak.hu/allami-tulajdonba-kerulnek-az-egyetemi-ppp-ingatlanok-valodi-gyogyir (Letöltés: 2015.09.07.)
} 